\title{
918 SOCIAL EXCLUSION AND MARGINALISATION OF HOMELESS PEOPLE: A CLARION SOCIAL WORK CALL FOR THE SPIRIT OF UBUNTU TO REIGN
}

\section{Timson Mahlangu, Phuti Kgadima}

Mr Timson Mahlangu, Social worker, Department of Health, Gauteng Province, South Africa.

Dr Phuti Kgadima, School of Social Sciences, Department of Social Work, UNISA, Pretoria, South Africa.

Timson Mahlangu: timsonmahlangu@gmail.com

Nathaniel Phuti Kgadima: kgadinp@unisa.ac.za

Timson Mahlangu, ORCiD: 0000-0003-4370-449X

Nathaniel Phuti Kgadima ORCiD: 0000-0002-6385-5378

Social work is committed to the advancement of human rights and social justice. One strategy for promoting social justice is to inculcate a human rights-based approach to social work practice. Using ubuntu as a theorical framework, this article initially explores social exclusion and the accompanying stigma that homeless people experience; it then examines how social workers could apply the principles of ubuntu to re-inscribe homeless people's human rights.

A qualitative study was undertaken with 14 participants who were purposively selected and also identified through snowball sampling. Data were gathered through semi-structured interviews and analysed thematically. Principles of credibility, transferability, dependability and conformability were judiciously adhered to in the research process. The findings indicate that homeless people are the most marginalised population of the community and they are exploited in a variety of ways.

Keywords: homelessness, homeless people, marginalisation, social exclusion, stigma, ubuntu 


\section{SOCIAL EXCLUSION AND MARGINALISATION OF HOMELESS PEOPLE: A CLARION SOCIAL WORK CALL FOR THE SPIRIT OF UBUNTU TO REIGN}

\section{Timson Mahlangu, Phuti Kgadima}

Mr Timson Mahlangu, Social worker, Department of Health, Gauteng Province, South Africa.

Dr Phuti Kgadima, School of Social Sciences, Department of Social Work, UNISA, Pretoria, South Africa.

\section{INTRODUCTION}

Homelessness is a complex phenomenon (Singh, Koiri \& Shukla, 2018; Watson \& Cuervo, 2017) with no singular definition, largely because of the diversity of contexts that homeless people face (Eissmann $\&$ Takeuchi, 2020). However, both academics and policymakers concur on three broad categories of homelessness, namely primary, secondary and tertiary homelessness. Primary homelessness denotes those living on the street pavements, derelict buildings or doorways, in parks, under bridges and bushes, dumping sites, taxi ranks, bus or train stations in metropolitan cities or rural towns without any form of conventional accommodation (De Beer \& Vally, 2017). Individuals who experience secondary homelessness are usually accommodated temporarily in specialised homelessness facilities and have to move from one form of accommodation to another. Such people may be children or women in shelters and orphanage homes (Ntakirutimana, 2015). The last category of homelessness is experienced by those individuals residing in accommodation under minimum community standards, including caravan parks and boarding houses short- and long-term (Ntakirutimana, 2015). This article examines the first category of homeless people, with particular focus on those living on the streets of the City of Tshwane, South Africa.

The article set out to interrogate the social exclusion and accompanying stigma that homeless people experience and how social workers could apply the principles of ubuntu to re-inscribe and restore homeless people's human rights. The condition of homelessness goes beyond just the lack of a home, but it also manifests the outermost states of marginalisation and denial of basic rights (Ghosh, 2020). Homeless people are often subjected to humiliation, indignity and insecurity (Sing, Koiri \& Shukla, 2018). They are stigmatised and perceived as different and undesirable (Watson \& Cuervo, 2017). Furthermore, this stigma excludes homeless people from societal institutions and services that could assist them with services such as accommodation. Leijten and de Bel (2020) argue that, although not topping the list of social rights, the right to housing is increasingly recognised in many international documents and national constitutions. Notably, Article 25(1) of the Universal Declaration on Human Rights (UDHR) states: "Everyone has the right to a standard of living adequate for the health and wellbeing of himself and of his family, including [...] housing [...]" (Leijten \& de Bel, 2020:95; United Nations, 2015). Similarly, the right to housing is enshrined in section 26 (1) of the Constitution of the Republic of South Africa (RSA, 1996) which guarantees "the right to have access to adequate housing".

\section{THEORETICAL FRAMEWORK}

Social exclusion and the accompanying stigma that homeless people experience is best explored through the lens of ubuntu. Social workers could apply ubuntu to re-inscribe and restore homeless people's human rights and dignity. The notion of ubuntu is a multifaceted concept because it cannot be assigned to a specific social context but tends to apply in diverse forms which depend on the context (McCluskey \& Lephalala, 2010). Quan-Baffour and Romm (2015:460) compare defining 'ubuntu' to trying to give a definition of 'time'. Everybody seems to know what 'time' is until they are asked to define it or detail its essential characteristics without which 'time' could not be 'time'. 
It is not the intention of this article to discuss all the diverse interpretations of ubuntu, but to indicate that as a noun ubuntu is widely used in different societies across Africa. For instance, in Angola, it is known as gimuntu, Botswana (botho), Burkina Faso (maaya), Burundi (ubuntu), Cameroon (bato), Congo (bantu), Democratic Republic of Congo (bomoto/bantu), Cote d'Ivoire (maaya), Equatorial Guinea (maaya), Guinea (maaya), Gambia (maaya), Ghana (biako ye), Kenya (utu/munto/mondo), Liberia (maaya), Malawi (umunthu), Mali (maaya/hadama de ya), Mozambique (vumuntu), Namibia (omundu), Nigeria (mutunchi/iwa/agwa), Rwanda (bantu), Sierra Leonne (maaya), South Africa (ubuntu/botho), Tanzania (utu/obuntu/bumuntu), Uganda (obuntu), Zambia (umunthu/ubuntu) and Zimbabwe (hunhu/unhu/botho/ubuntu) (Gade, 2012:486; Mugumbate \& Chereni, 2019:28). In this article the South African understanding of the concept is consistently applied. In the Zulu language of South Africa, the word ubuntu symbolises being human or humaneness (Mugumbate \& Chereni, 2019:28). Moreover, Mugumbate and Nyanguru (2013: 82) conceptualise ubuntu as "a form of humanism which can be expressed in the phrases 'I am because of who we all are.' It is aptly summarised in the Nguni proverb (Gade, 2012:487) 'umuntu ngumuntu ngabantu', which translates into 'a person is a person through other people"' (Gade, 2012, 318; Van Breda, 2019:339). Therefore, the notion of ubuntu promotes the spirit of "caring and community, harmony and hospitality, respect and responsiveness that individuals and groups exhibit for one another" (Ngunjiri, 2016:225).

The social work profession has been recognised for its importance in promoting access to human rights (Šadić, McPherson, Villarreal-Otálora \& Bašić, 2020) and social justice (Sewpaul 2016). Therefore, the social work profession should, as a matter of principle, engage with the notion of ubuntu (Mugumabate \& Chereni, 2019). Ubuntu is consistent with the values and ideals of social work, notably "human solidarity, empathy, and human dignity" (Van Breda, 2019:441). Secondly, ubuntu is associated with the core social work values of social justice (Schreiber \& Tomm-Bonde, 2015; Van Breda, 2019). In essence, it is the mission of social work to promote social justice (Mugumbate \& Chereni, 2019). Social justice refers to:

an ideal condition in which all members of a society have the same basic rights, protection, opportunities, obligations, and social benefits ... [it] is also about ensuring that resources are equitably distributed (Patel, 2015:147).

According to Van Breda (2019), theory in social work serves two main purposes: making sense of the world (explanatory theory) and guiding social work practice (practice theory). Admittedly, little work has gone into developing the conceptual foundation of ubuntu in such a way that it begins to constitute a 'theory' for social work practice (Van Breda, 2019). However, it is not the goal of this article to establish definitive or 'correct' social work theory or practice. Rather, the goal is to contribute towards the "creation of a more just world" (Shimei, Krumer-Nevo, Saar-Heiman, Russo-Carmel, Mirmovitch \& Zaitoun-Aricha, 2016). As an ontological orientation, the notion of ubuntu calls for the elimination of division and othering and to champion unity across diversity, including social distancing (Van Breda, 2019).

\section{METHODOLOGY}

This article utilises a qualitative approach that allowed for the identification and elaboration of the breadth and depth of the participants' subjective experiences (Funk \& Kobayashi, 2014). An exploratory design was employed to investigate homelessness, while the descriptive design was appropriate to provide an accurate account of homeless people's lived experiences (Grove, Burns \& Gray, 2013).

The goals of this study are two-fold namely, (i) to explore social exclusion and the accompanying stigma that homeless people experience, and (ii) to examine how social workers could apply the principles of ubuntu to re-inscribe homeless people's human rights.

To achieve the goal of the study, the following research objectives were formulated:

- To explore and describe homeless people's challenging experience of living on the street;

Social Work/Maatskaplike Werk 2021:57(4) 
- To provide recommendations for social workers to apply the ontological orientation of ubuntu to reinscribe and restore homeless people's human rights and dignity.

Customarily, a qualitative inquiry calls for the formulation of research questions from the outset rather than relying on hypotheses (Creswell, 2016). Therefore, the article responds to the following two interdependent central questions:

- How do homeless people experience social exclusion and the accompanying stigma?

- How could social workers apply the ontological orientation of ubuntu to re-inscribe and restore homeless people's human rights and dignity?

Homeless people had to meet the following criteria for inclusion in the study:

- They should belong to the primary category of homelessness in that they should be living on the street pavements, derelict buildings or doorways, in parks, under bridges and bushes, dumping sites, taxi ranks, bus or train stations in metropolitan cities or rural towns without any form of conventional accommodation;

- They should be 18 years or older during the study;

- They should have been homeless for two years or longer;

- They should have been residing in the City of Tshwane in the Gauteng Province, South Africa; and

- They should be able to speak Setswana or English.

The choice of the City of Tshwane as a site and context was informed by the observation that most homeless people are concentrated in metropolitan areas (Renkin, 2015:). Du Toit (2010) contends that in South Africa the concentration of homeless people is evident on the streets of metropolitan cities more than in rural towns. Many homeless people migrated from rural to metropolitan cities to escape poverty, ironically. Some authors caution that with the upsurge of urbanisation, migration and unemployment, a larger number of underprivileged individuals are highly at risk of becoming homeless (Schenck, Roman, Erasmus, Blaauw \& Ryan, 2017).

Face-to-face semi structured interviews were used to generate data and data saturation was reached after 14 homeless people were interviewed. The interviews were conducted in Setswana and English for 3045 minutes. The Setswana interviews were translated by the author 1 and verified by author 2 . The desired outcome of the translations was to clarify the meaning and not necessarily for literal equivalence. The authors relied on their knowledge and understanding of the participants' indigenous languages to provide a comparable translation and interpretation.

In order to draw a sample from the population, purposive and snowball sampling techniques were employed. The data were analysed thematically using Tesch's approach as outlined in Creswell (2014). Credibility of the findings was ensured through triangulation by consulting with various knowledgeable sources on homelessness. Confirmability was achieved through documenting ideas during data collection and analysis in the form of a journal. To ensure dependability, the findings were validated though the use of an independent coder in the data analysis. In this study the element of transferability was enhanced by providing thick descriptions of the findings with appropriate quotations.

Ethical clearance was provided by the University of South Africa (UNISA), Social Work Departmental Research and Ethics Committee (Reference number: 2019-SWREC 49495259). The following ethical considerations were observed: obtaining written informed consent, assuring confidentiality, protecting participants from harm, and management of the research data. With the ethical principle of informed consent, participants were furnished with information regarding the purpose of the study process, and the risks and benefits associated with participating in the study. The concept of confidentiality is linked to anonymity as confidentiality is operationalised when anonymity is maintained when reporting the data. The ethical principle of confidentially was adhered to by not revealing the participants' identities, but 
instead reporting the data anonymously by using pseudonyms. After completing each of the interviews in the study, the participants were informed that a debriefing service was available if the interview triggered any negative emotions. However, no participants expressed a need for the debriefing service.

\section{PRESENTATION AND DISCUSSION OF FINDINGS}

Table 1 provides the biographical data of the participants.

\section{TABLE 1}

BIOGRAPHICAL PROFILE OF THE PARTICIPANTS

\begin{tabular}{|l|l|l|l|l|l|l|}
\hline Participants & Gender & Race & Age & Education & \multicolumn{1}{|c|}{ Occupation } & $\begin{array}{c}\text { Duration as } \\
\text { homeless }\end{array}$ \\
\hline A & M & Black & 50 & BA Degree & Unemployed & 3 years \\
\hline B & M & Coloured & 32 & BA Degree & Unemployed & 2 years \\
\hline C & M & Black & 30 & Diploma & $\begin{array}{l}\text { Employed (Stock } \\
\text { taking) }\end{array}$ & 2 years \\
\hline D & M & Black & 63 & $\begin{array}{l}\text { Never went to } \\
\text { school }\end{array}$ & Unemployed & 3 years \\
\hline E & M & Black & 34 & Certificate & Unemployed & 5 years \\
\hline F & M & Coloured & 27 & BA Degree & Unemployed & 2 years \\
\hline G & F & Black & 30 & Grade 11 & Unemployed & 5 years \\
\hline H & F & Black & 46 & Grade 8 & Unemployed & 19 years \\
\hline I & M & Black & 42 & Grade 12 & Unemployed & 26 years \\
\hline J & M & Coloured & 21 & Grade 11 & Unemployed & 2 years \\
\hline K & M & Black & 31 & Grade 11 & Unemployed & 6 years \\
\hline L & M & White & 33 & Grade 9 & Unemployed & 9 years \\
\hline M & M & White & 42 & Grade 7 & Unemployed & 21 years \\
\hline N & M & Black & 35 & Grade 11 & Unemployed & 5 years \\
\hline
\end{tabular}

The biographical profile reveals few notable features. First, the majority of the participants were males. This gender disparity is somewhat expected, because there are fewer females on the streets, which may be a consequence of the difficult street living conditions (Kok, Cross \& Roux, 2010). Prinsloo and Van der Bergh (2017) suggest that some homelessness interventions, such as shelters and drop-in centres, target female homeless people, which may explain the fewer female than male homeless people in this sample.

Second, the majority of the participants were Black Africans. Although it is argued that homelessness does not distinguish along the lines of race, gender and age (Commonwealth of Australia, 2008), in South Africa black African groups are more prone to homelessness than others. In post-apartheid South Africa, street homelessness needs to be comprehended relative to the history, politics and socio-economic contexts of the country (Sanchez, 2010). The forced removals of communities under the apartheid regime exerted an indelible historical impact on black individuals becoming homeless in South Africa (Mangayi, 2014). Since the service industry is the primary driver of the South African economy, many individuals are attracted to the metropolitan cities in the hope of securing employment or improving their standard of living, and the least successful of those individuals ultimately end up as homeless (Morrow, 2010).

Contrary to the general assumption that homeless people are illiterate, or that they have only reached the primary level of education (Ghosh, 2020), a significant number of the participants had obtained postmatric qualifications, with three having obtained each a Bachelor's degree.

Participants were invited to share their challenging experiences of being homeless. From their responses, four themes emerged from the data analysis and are presented in Table 2 below. 
TABLE 2

THEMES

\begin{tabular}{|l|l|}
\hline Theme 1 & Exploitation, marginalisation and social exclusion of homeless people \\
\hline Theme 2 & The experience of stigma and discrimination by homeless people \\
\hline Theme 3 & $\begin{array}{l}\text { Indifferent service from public and private service providers towards homeless } \\
\text { people }\end{array}$ \\
\hline Theme $\mathbf{4}$ & Lack of basic facilities \\
\hline
\end{tabular}

\section{Theme 1: Exploitation, marginalisation and social exclusion of homeless people}

Several scholars describe homelessness as a form of social exclusion (De Beer \& Vally, 2017; Mangayi, 2014; Manthorpe, Cornes, O'Hallorans \& Joly, 2015). Social exclusion is a continual process, denying certain individuals, groups or community members access to resources needed for participation in the social, economic and political activities of society (Pierson, 2010).

Homeless people are exploited in a variety of ways. Often homeless people are subjected to homelessness intervention as passive service recipients (Parsell, Tomaszewski \& Phillip, 2014). One of the participants described how homeless people are exploited by different stakeholders who had pledged to offer them support and services:

Homeless people get exploited by the very same people that claim to be caring for them. When I say the very same people, I mean number one, the government institutions, government stakeholders which is now NGOs [non-governmental organisations], NPOs [non-profit organisations], CBOs [community-based organisations] and including churches [FBOs, faithbased organisations]. How they are exploiting people - like people will come to a public park and they will find a whole lot of homeless people there and make them sign papers and take pictures and make videos. The following day when I open their website I find all the things that are written on the website about the homeless people, that is the same way they ask for sponsorship and donations from other people but at the end when they get all those things, none of the homeless people gets a dime of any of those things that they have received. Firstly, if it is material things, they sell it, and if it is cash, it goes into their banking accounts and they even forget that they got sponsors because of the pictures and videos - that is what I mean about exploitation. In plain English, it is slavery. They use homeless people but at the end they do not share with us the resources and that is the problem. I do not want them to give everything to homeless people but just share. (Participant $\mathrm{M}$ )

Allegations levelled against NPOs are also related to unfair treatment of homeless people, withholding of donations, such as clothing and blankets destined for the homeless people, and preferential treatment for foreign nationals. One of the participants expressed his experiences with the service providers for homeless people as follows:

I like to be treated as a human being... everyone wants to be treated like a human being, not like animals. You see the organisations get sponsors through us, they get a budget and everything, but they give us [homeless people] on the street dry bread and those things are ours and not theirs. Every time before we eat at organisations, we have to register our names so that they can get sponsors and when they get sponsors, we do not benefit... they are only using us, all the organisations... they get sponsors in the name of the homeless people, but we do not benefit. If you go to them and ask for a shirt, a trouser [sic] or whatsoever, they will tell you there is nothing but if you go to their store rooms, you will see the clothes. (Participant I)

One of the participants was sceptical about the attitude of the media towards the plight of the homeless people, as explained in the extract below: 
In terms of our media when they want to know things, you know we are sitting with a media that only publish what is sellable. The only reason why we see ourselves in media today is because of our [homeless] people who died, if nobody had died, we would not have been in the media. Yes, they came when we started fighting with the system and that is when they showed up because that is the kind of action that they want - negative action, but with positive action they are not interested. (Participant B)

The participant's explanation is consistent with the observation that established interventions assist homeless people who encounter several challenges, such as allegations of mismanaging resources meant for homeless people (Shava, 2019). However, citing the study by Sanchez (2010), Schenck et al. (2017) contend that NGOs and FBOs generally have a good understanding of the complexity of being homeless and their services are widely regarded as valuable.

Homelessness is often associated with vagrancy and punitive sanctions are directly targeted at these socalled vagrants (Rusenko, 2018) and they are criminalised (Pospěch, 2020). However, it is not the act or condition of being homeless itself that is criminalised or the activities which are associated with homelessness such as begging (Young \& Petty, 2019). In an attempt to make public spaces inaccessible to homeless people, law enforcement officers often charge homeless people with a range of offences relating to public order or public nuisance (Young \& Petty, 2019). Consequently, homeless people are also subjected to harassment by law enforcement officers, as evident in the extract below:

Police officers will find you [the homeless person] sleeping and abuse their authority; they find you sleeping and pour a bucket of cold water on you. It is winter now; can you see people who are supposed to protect you... now you are a suspect just because you are sleeping there. I do not know whether their perception is that one of rejection or that one of generalising that we are all nyaope users? If they [police officers] find you sleeping, they just harass you and abuse their authority. Your rights are stripped away and where will you report if a police officer does that? If you report a police officer to a police officer, you know the case will not go anywhere. We just suffer in silence. We just survive, I have lost everything, I have lost my laptop, it is survival of the fittest out here and this thing of killing is just a final straw, but you lose everything. (Participant A)

This finding demonstrates that homeless people are at risk of harassment by law enforcement officials, who are supposed to protect them on the street. Similarly, Bullock, Truong and Chun (2017) report that police harassment of homeless people is common. This official criminalisation of homelessness is concerning as it raises serious questions about respect for human rights and dignity. It seems there is an effort to "eradicate or annihilate" homeless people by law enforcement officers; hence some authors (Johnsen, Watts \& Fitzpatrick, 2021:356) conceptualise such interventions as "genocidal" which in the authors' view is "brutal, cruel and inhumane". For instance, some of the cities have installed studs, often referred as 'homeless spikes' to prevent rough sleepers from bedding down.

\section{Theme 2: The experience of stigma and discrimination by homeless people}

Stigma is the result of a person's individual attributes being perceived as different and undesirable (Watson \& Cuervo, 2017). Similarly, homeless people are stigmatised as deviant and not quite human. They are often considered as 'outsiders' and treated as strangers. Van Breda (2019) views such a dehumanisation of other people as 'othering'. Othering divides the world into in-groups and out-groups as a way of building the self in relation to inferior others. Van Breda (2012:181) explains: "We insiders are viewed as good and virtuous, while those outsiders are bad and evil ... They are less than us... less than human, and less than worthy." The notion of ubuntu embraces connection and compassion over selfishness; it recognises the full humanity of every person, not only those who are like us or part of our in-group (Van Breda, 2019).

Although some participants are actively involved in addressing their situation of homelessness, they often encounter structural and social barriers (Thompson, Ryan, Montgomery, Lippman, Bender, \& Fergus, Social Work/Maatskaplike Werk 2021:57(4) 
2016) such as discrimination and stigmatisation. Some of the barriers to the effective involvement of the homeless people in addressing homelessness are emphasised in the extracts below:

You try to knock on doors, like I say we have an organisation that is trying to address the grievances of homeless people but that perception [generalising, labelling and stigmatising homeless people]... This negotiation for a shelter has been taking long. Mind you, the municipality is part of government but that negative perception about homeless people... It has been long that they have been negotiating for a shelter, a basic thing [with emphasis]. And now I suspect why they are positive now, it is because of the deaths [of murdered homeless people by a serial killer], they feel the pressure because of the deaths. (Participant A)

A home provides a sense of security and comfort. However, living on the streets severely compromises the safety of homeless people (Heerde \& Pallotta-Chiarolli, 2020). They are often exposed to physical risks such as murder, as one of the participants explained in the extract below:

Lack of shelter perpetuates the outcomes such as deaths. Today [20 June 2019] it was announced that a fifth body of a homeless person was found. We do not know when it will stop. Should they have addressed this thing taking it into consideration right at the beginning to put those people in a secure place, we would be talking something different. So that is the challenge we have and the perception itself makes it... it affects you negatively as you attempt to address the grievances and concerns of us as homeless people. (Participant A)

Negative perceptions of the homeless people may also hamper service delivery. For instance, the negative perceptions by public service officials concerning the homeless people as criminals and a lack of respect for the homeless people may create challenges in providing services (Phillips \& Kuyini, 2018; Prinsloo \& Van der Bergh, 2017). One of the participants illustrated how homeless people are treated as inferior human beings because they are often stereotyped by society:

First is the perception of society, government, and all stakeholders because we are at the lowest rank of humanity. Everyone rejects you like. You are cast out; you are actually cast out of the gate of humanity. Those who are working when they walk to work in the morning and see you lying there, they see a dog. When people see you, they generalise because there are others [homeless people] who are on the streets for other purposes doing crime and smoking nyaope [drug]. They generalise all of you and only to find out we are not the same. So those are the challenges, the perception of society, the perception of government and all stakeholders of society... the employers. When the society think of homeless people, they think of a person with leprosy, and it has nothing to do with that. (Participant A)

One of the common aspects of individuals experiencing homelessness explored by several scholars (Donley \& Jackson, 2014; Meanwell, 2012; Rayburn \& Guittar, 2013; Toolis \& Hammack, 2015) is that of stigma and discredited identities. Stigmatisation occurs when an individual identity does not conform to social expectations when certain individuals, such as the homeless people, cannot fit the standards set by society (Belcher \& Deforge, 2012; Hudson, 2016). On the grounds of these negative attitudes, homeless people are devalued and as such are, in a sense, already guilty of whatever label society chooses to attach (Belcher \& Deforge, 2012).

A presentable person commands respect and may be allowed entry into different establishments. Homeless people often find it difficult to access the necessary services they need (Moya, Chavez-Baray, Martinez, Mattera \& Adcox, 2018; Watson \& Cuervo, 2017). Conversely, a homeless person with dirty and torn clothes may be denied access even to public institutions, as illustrated by the extract below:

It is very challenging being homeless, and how you present yourself to people, sometimes you are dirty and there are some places you need to enter but they won't allow you because of how you look. For example, maybe I need to go to the library and gather some information, but unfortunately, they won't allow me on the basis of how I look, because I am dirty and 
even though they can allow me to enter... I do not think that they will help me or give me the proper service that I want. (Participant E)

Homeless people are often subject to generalisation and associated with other conditions such as substance use, mental illness and criminality (Donley \& Jackson, 2014). They are often viewed as not "worthy" of equal rights or access to social resources (Belcher \& Deforge, 2012). Similarly, a participant named Angela in a study by Watson and Cuervo (2017) focused on the marginalisation of homeless people and described how the degradation associated with homelessness affected her subjectivity and thus compromised her interactions with support services to the point that they ceased to be a resource for her. She had this to say:

I felt pretty helpless. I knew that there were services out there, but I'd just been there and done that so many times that I really didn't have a lot of self-esteem, ... it's pretty degrading actually.'

\section{Theme 3: Indifferent service from public and private service providers towards homeless people}

Homeless people are often affected by corruption. Lough (2008) describes corruption as a void in the government systems whereby the homeless people are already victims of injustice and inequality. Corruption causes practical problems and frustrations in the day-to-day lives of homeless people as they do not have access to basic services (Orjuela, Herath \& Lindberg, 2016). Corruption creates an atmosphere of helplessness, mistrust and isolation, further limiting perceptions that homelessness can be addressed (Jamal, 2019; Lough, 2008).

Some participants reported that certain government agencies are unresponsive and corrupt, and they do not listen to their needs, simply because are deemed homeless. Some of the participants reflected on the ways in which the state relates to them in the comments below:

The challenges that I am facing is the ignorant government. That is the biggest challenge because we are sitting with people in offices who are ignorant about the challenges of homeless people., I don't know how people are benefiting from people being on the streets. It is only a logical thing that comes in my mind, [with emphasis] why people are so determined to keep people on the street. We go to people and say you know what I am trying to fight this thing [homelessness] because it is not good for us as people, so I need your [government] support in this and that and there is no support at all. ... The corrupt system [government] was designed to only favour certain groups of people, so if you are not part of that group of people you will never get anything, and you will never get anywhere. Unfortunate as homeless people, we are not part of that system but at the same time by fighting the system I refuse to be part of the system and I refuse that system to control my life because I can see it is not benefiting me or other people that it should be benefiting. (Participant B)

One of the biggest challenges is that our system [government] does not cater for individuals, so if I am homeless, I am an individual and I go to our government, they will ask me who is representing you? We have stakeholders, we have organisations and they do not do anything at all. So, it becomes a big challenge. (Participant E)

So, it is challenging to stay true to yourself and others while you are homeless and fighting the system [government]. And it is the corrupt system that we have in our country that is making life very difficult while it was supposed to be easier. (Participant $\mathrm{C}$ )

Civic movements, such as those driven by NPOs, are often perceived as important role-players in addressing societal concerns such as homelessness. However, participants have a different view and contrary experience from that of the general public, who believe that NPOs have an important role in the support of a broader range of development activities, such as addressing homelessness (Munisa, 2010). 
The participants reported that certain NPOs often sabotage their initiatives to address homelessness, as explained below:

We often experience certain NGOs as stumbling blocks. There are certain NGOs with leaders who have twisted mind-set. They think that if they can address and eradicate street homelessness, their NGOs will no longer be useful... forgetting that homelessness will never end, each and every day there is a person who comes to town [Tshwane CBD] and he might be desperate and become homeless. The challenges that we face most of the time is NGOs. And ... we lack resources on the street, let's say for instance there is a meeting of people who are trying to address street homelessness in Centurion, I am just a person, I do not even have R20 to buy a train ticket. These are some of the challenges I face, and let's say I want to print out some letters and I do not have a computer or a printer... As I have said the lack of resources, particularly administrative resources... NGOs are using their capacity to go and hijack some of our movements on the street. Now there is a homeless people movement on the street that is fighting for a shelter. We just got a building yesterday [20 June 2019], and if we are only homeless people and another NGO claim to support us... immediately when the MEC [Member of the Executive Council] says I can give homeless people a building, NGOs are going to hijack the building. One thing I know, NGOs have been hijacking a lot of buildings in the name of homeless people and at the end they do not use the building for matters of street homelessness. (Participant C)

It is very challenging being homeless, and how you present yourself to people, sometimes you are dirty and there are some places you need to enter but they won't allow you based on how you look. For example, maybe I need to go to the library and gather some information, but unfortunately they won't allow you on the basis of how I look, because I am dirty and even though they can allow me to enter... I do not think that they will help me or give me the proper service that I want. (Participant E)

The participants' encounters with various stakeholders contradict Shava's (2019) assertion that the role of NPOs in addressing homelessness remains important, as they complement government interventions. NPOs which are not established by the government are not typically motivated by profit, although in some cases NPOs may receive funding from the government (Munisa, 2010) to survive and fulfil their mission (Kaloudis, 2017). When NPOs relegate their clients to the margins in developing policies and guiding documents designed to offer services, then this culminates in mistrust from homeless people (Prinsloo \& Van der Berg, 2017). Homeless people are misrepresented by the NPOs in the acquisition of resources and ultimately the homeless people do not benefit.

\section{Theme 4: Lack of basic facilities}

Homeless people are among the most marginalised population of the community. Being homeless implies that the person is exposed to health problems, runs the risk of getting hurt, being exploited in a variety of ways, and does not have access to basic facilities or proper food (Schenck et al., 2017:267). Homeless people spend most of their lives on the street without basic amenities, such as drinking water and sanitation (Ghosh, 2020). This deprivation does not only infringe homeless people's basic rights, but it also makes them feel less human, devalued and undignified.

Personal hygiene is difficult to maintain on the street, as clean water is a scarce resource (Padgett \& Priyam, 2019). Four of the participants noted how lack of access to basic amenities and facilities affect them in the following extracts:

You do not bath on the street and even if you do, you do not bath properly and become a health hazard to the society because of unhygienic odour. Anyway, where will you bath when you are living on the streets, you must use a 2-litre bottle and bath like a cat. Life is highly impossible on the street... it is not life and even to eat... (Participant D) 
I have not washed my mouth in a while, now everything has been stolen from me. If you have shelter, then you have security, all your belongings will be secured. (Participant A)

Now it is cold and when winter ends, rainy season will begin and we sleep where there is no roof or even a door to lock, you just sleep. (Participant F)

The challenges are that at times I have to sleep on an empty stomach; when it rains it is difficult as you cannot even sleep. We do not have enough blankets and it is winter... it is too cold; we are struggling and that is the challenge I know. The struggles are having to sleep on an empty stomach and having to go around searching for food in dustbins in order to have something to eat. (Participant J)

Human life and development are based on the extent to which individuals can satisfy their basic needs, such as access to water and toilets (Aderamo \& Aina, 2011). Access to drinking water is a primary need for human survival and protection from a whole host of diseases (Manomano, 2018; Mishra \& Shukla, 2015). Inadequate sanitation and hygiene, particularly concerning access to clean water and toilets, often make living conditions for the homeless people hazardous (Manomano, 2018). Manomano (2018) further identified waterborne disease and premature death as the consequences of a lack of basic essential amenities amongst the homeless population.

Ubuntu is a humanist approach that accentuates human dignity (Ibrahima \& Mattaini, 2019). Dignity is a fundamental feature of human existence, which in basic terms implies that every person has inherent equal worth (May \& Daly, 2020). However, because of their homelessness, people become "voiceless, powerless and live without [human] dignity" (Schenck et al., 2017:268). The lack of access to basic human amenities and facilities may result in a loss of dignity and self-worth. For instance, access to toilet facilities is one of the important essential aspects of sanitation (Mishra \& Shukla, 2015); this integral part of public hygiene and health as well as dignity allows a person to feel important and valuable in their relationship with others, respected even in situations of threat (Simoes \& Sapeta, 2019). One of the participants explained the relation between human dignity and access to basic human amenities and facilities:

To me dignity means access to basic resources like shelter, like a place to relieve yourself, that is the most... it makes me cry when I think that every time when I have to relieve myself I must walk to the nearest health centre and pretend that I am going to see a person who is sick without even greeting the security guard, going there to relieve myself and at the same time steal a little bit of toilet paper, then go back. Every time I have to walk there because of how pressed I am, I have to hold myself because I cannot lower myself as a person to such an extent that I can pee anywhere in the open, so I have to walk there as it is the only place that is accessible to me or to a petrol filling station. But some of the garages you must pay money to use their toilets and you have nothing. So, when I talk about dignity, I am talking about such things. (Participant A)

Access to drinking water and toilets is essential for a secure, dignified and healthy life for every human being regardless of his or her socio-economic status (Kumar, 2015). Consequently, those homeless people lacking access to basic facilities, such as toilets, may resort to defecating in open public spaces. They also lose important documents such as their identity documents (IDs) and valuable goods as they do not have a safe place to store them. One of the older homeless people illustrated his experience as follows:

I do not have an identity document [ID]. My ID and old-age grant card provided by South African Social Security Agency [SASSA] got stolen from me; at least if I had a grant card maybe I will be getting a grant and to get it they need ID at SASSA. (Participant D)

The extract suggests a need for facilities where homeless people can store their important documents, such as identity documents required to apply for social assistance grant (SASSA, 2020). By obtaining 
the grant, homeless people may carve pathways from homelessness through paying to stay at an old-age home.

\section{IMPLICATIONS FOR SOCIAL WORK PRACTICE}

It is apparent that ubuntu has important social work implications. From its conception, social work has always been committed to promoting human rights, working on the side of social justice (Šadić et al., 2020). Consequently, Horsell (2017) urges social workers to focus on challenging the structural societal conditions that diminish homeless people's rights and at the same time initiating interventions that resist oppressive structures that deny these basic rights. Similarly, the European Region of the International Federation of Social Workers (2010) has taken important steps in promoting a human rights approach across countries by emphasising that "responding to human rights is the responsibility of the social work practitioner" by publishing the Standards in Social Work Practice Meeting Human Rights (Iovu, 2019:2). One strategy for promoting social justice is to inculcate a human rights-based approach to social work practice (Šadić et al., 2020). Embracing a human rights-based approach to social work practice requires the professional to see clients as rights holders who may be vulnerable to violations of those rights (Iovu, 2019). Admittedly, in order to promote social justice and human rights, social workers must have the requisite tools to help homeless people claim their rights. Therefore, this article also discusses how social workers could respond to homelessness.

Homeless people comprise one of the most vulnerable and marginalised groups in society (Wu \& Karabanow, 2020); they represent the most obvious and severe manifestation of the unfulfilled human right to adequate housing (Schenck et al, 2017). Effective responses by practitioners, policymakers and researchers to homelessness require an understanding of the complexity of the issue (Sample \& Ferguson, 2020). Traditionally, the social work profession has focused primarily on the influence of the immediate environment in contributing to and alleviating human problems, rather than on related structural or systemic problems(Sample \& Ferguson, 2020). But the social work profession does not exist in a vacuum. It operates between the forces of social control and social change (Šadić et al., 2020:1). In post-apartheid South Africa the profession operates within an environment of past national trauma in combination with the current intensified circumstances of poverty, unemployment, violence, social inequality and persistent lack of effective service delivery to the majority of South Africans. Most of the people continue to endure the long-term implications of apartheid policies (Abdullah, 2015). The apartheid regime implemented spatial policies resulting in a massive number of forced removals and dispossession in urban and rural areas (Cross, Seager, Erasmus, Ward \& O'Donovan, 2010). Forced removals were a fundamental strategy of the apartheid regime to deprive black African individuals of all their political rights along with their citizenship (Kgatla, 2013). Even after decades of democracy in South Africa, the legacy of apartheid continues to determine the wellbeing of the majority, including the homeless population (National Planning Commission, 2012).

The ideals of social justice work against penalising people for behaviour caused by factors largely outside their control (Johnsen et al., 2021). Thus, to address these challenges, social workers should focus on challenging the structural societal conditions that diminish their clients' rights (Horsell, 2017). Social workers are in a privileged position to contribute to social justice and human dignity because, on a daily basis, they witness the suffering engendered in the lives of people by political decisions and policies (Sewpaul, 2016:). Abdullah (2015:43) further advises social work professionals to advance a culture of human rights beyond "narrow formulations of human rights rooted in Western society to instead address broader social injustices."

\section{RECOMMENDATIONS FOR SOCIAL WORK PRACTICE, EDUCATION AND RESEARCH}

\section{Recommendations for social work practice}

Traditionally, social justice policy approaches to homelessness have understandably focused on the distribution of resources, particularly in the form of providing accommodation. However, this article 
recommends social work methods that are incorporated into a rights-based approach practice (Iovu, 2019) and are summarised below.

Recommendation 1: Social workers should involve clients as equal partners or even leaders in all stages of work, namely assessment, intervention and evaluation on both individual and agency levels. The concept of ubuntu expresses the value of the collaborative role and emphasises the importance of individuals collaborating to address a shared goal (Coghlan \& Brydon-Miller, 2014). Efforts by the government to address homelessness fail to address street homelessness because homeless people are often considered as needing salvation rather than as collaborators. Handin and Wille (2017) emphasise that homeless people have insight into the resources they require to exit homelessness and can be partners with service providers in the development of the appropriate interventions. Without the involvement of the homeless people in policy development and service provision, there is a great risk that a unique understanding of what constitutes effective service delivery to the homeless is curtailed (Phillips \& Kuyini, 2018).

Recommendation 2: Social work intervention with homeless people should aim at both individual (micro) and social (macro) levels to help them with their immediate problems and also prevent those problems from recurring in the future. Community work is aligned with the principles of ubuntu in that it is focused on the values of cooperation and collaboration (Mugumbate \& Nyanguru, 2013). However, ubuntu in the person-in-environment (PIE) perspective in social work goes beyond the individual and focuses on relationships between people (Van Breda, 2019). As is commonly said in many African cultures and communities, "It takes a village to raise a child" (Mugumbate \& Chereni, 2019:28) and therefore "your neighbour's child is your own [child]" (Mugumbate \& Nyanguru, 2013:86).

Recommendation 3: Social workers should create professional alliances that cross professional and social boundaries for the purposes of helping clients and promoting change in the community. In view of homeless people's lack of access to basic human amenities and facilities, such as sufficient food, water, healthcare services, education and shelter, it is recommended that social workers working in the area of homelessness should partner or collaborate with stakeholders, such as the Departments of Human Settlement, Water and Sanitation, Health, Social Development, Police Services as well as institutions such as Lawyers for Human Rights, to advocate for the rights of the homeless people to shelter and healthcare.

\section{Recommendation for social work education}

Recommendation 4: Social workers should be equipped with the requisite tools to promote social and human rights, which are key components of ubuntu (Šadić et al., 2020). It is therefore recommended that, from the first year, social work students should be exposed to human rights discourses, with an emphasis on the rights of vulnerable groups such as homeless people. Applicable themes to be addressed should include, but not be limited to, poverty, applicable international and national human rights standards, human rights violations and effective advocacy strategy.

Recommendation 5: Strategies to eliminate homelessness should go beyond the issue of shelter. Social workers should, therefore, build the homeless people' skills in both the personal and political realms, so that they can participate in changing unjust personal and political conditions. Social workers should forge partnership with institutions of higher learning and further education and training to intensify skills development centres, advancing homeless people and presenting them with job opportunities in the labour market.

\section{Recommendation for social work research}

Recommendation 6: Although much has been written about ubuntu, its meaning and usage in the body of social work literature remains limited. Some authors argue that there is a general tendency to conceptualise ubuntu just as being concerned about one's neighbour, when in actual fact it has the potential to offer a clearly defined and effective conceptual framework (Van Breda, 2019). Therefore, a

Social Work/Maatskaplike Werk 2021:57(4) 
concerted effort should be made to conceptualise ubuntu as one of the key theoretical frameworks within social work, both in academia and in practice.

\section{CONCLUSIONS}

This article highlighted the point that homeless people remain amongst the most marginalised population in society. Therefore, interventions to address homelessness should go beyond just addressing the material aspects of this phenomenon and also focus on non-material aspects such as restoring human dignity, facilitating access to human rights and challenging structural barriers that continue to marginalise, exploit and stigmatise homeless people. Applying the principles of ubuntu is suggested as the most appropriate approach to this conundrum, as ubuntu is associated with the fundamental social work value of social justice which acknowledges the basic human rights of all members of society, especially marginalised groups such as the homeless. The article further calls for respect and compassion for the homeless. We contend that recognising the dignity of the homeless is essentially a humanising protocol.

\section{REFERENCES}

ABDULLAH, S. 2013. Multicultural social work and national trauma: Lessons from South Africa. International Social Work, 58(1): 43-54.

ADERAMO, A. J. \& AINA, O. A. 2011. Spatial inequality in accessibility to social amenities in developing countries: A case from Nigeria. Australian Journal of Basic and Applied Sciences, 5(6): 316-322.

BELCHER, J. R. \& DEFORGE, B. R. 2012. Social stigma and homelessness: The limits of social change. Journal of Human Behaviour in the Social Environment, 22: 929-949.

BULLOCK, H. E., TRUONG, S. V., \& CHUN, L. 2017. Combating social exclusion: "safe space" and the dynamics of inclusion at a homeless farming site. Journal of Poverty, 21(2): 166-192.

COGHLAN, D. \& BRYDON-MILLER, M. 2014. The Sage Encyclopedia of Action Research, vol. 2, SAGE Publications Ltd, London. Available from http://dx.doi.org/10.4135/9781446294406. [Accessed 02/08/2018].

COMMONWEALTH OF AUSTRALIA. 2008. The road home: A national approach to reducing homelessness. Canberra Business Centre: Department of Families, Housing, Community Service and Indigenous Affairs.

CRESWELL, J. W. 2014. Research design: qualitative, quantitative and mixed methods approaches. $4^{\text {th }}$ ed. Thousand Oaks: SAGE Publications.

CRESWELL, J. W. 2016. 30 Essential skills for the qualitative researcher. London: SAGE.

CROSS, C., SEAGER, J., ERASMUS, J., WARD, C., \& O’DONOVAN, M. 2010. Skeletons at the feast: A review of street homelessness in South Africa and other world regions. Development Southern Africa, 27(1): 5-20.

DE BEER, S. \& VALLY, R. 2017. (Finding) Pathways out of homelessness: An engaged, transdisciplinary collaborative in the City of Tshwane. Development Southern Africa, 34(4): 385-398.

DONLEY, A. \& JACKSON, E. 2014. Blending in: the presentation of self among homeless males in a gentrifying environment. Theory in Action, 7(1): 46-64.

DU TOIT, J. L. 2010. Local metropolitan government responses to homelessness in South Africa. Development Southern Africa, 27(1): 110-128.

EISSMANN, I. \& TAKEUCHI, D. 2020. Homeless women in Chile: Examining daily life capabilities. International Social Work, $0(0):$ 1-14. 
FUNK, L. M. \& KOBAYASHI, K. M. 2014. From motivations to accounts: An interpretive analysis of "living apart together" relationships in mid- to later-life couples. Journal of Family Issues, 37(8): 11011122.

GADE, C. B. N. 2012. What is Ubuntu? Different interpretations among South Africans of African descent. South African Journal of Philosophy, 31: 484-503.

GHOSH, S., 2020. Understanding homelessness in Neoliberal City: A study from Delhi. Journal of Asian and African Studies, 55(2): 85-297.

GROVE, S. K., BURNS, N. \& GRAY, J. R. 2013. The practice of nursing research. Missouri: Elsevier.

HANDIN, J. \& WILLIE, D. E. 2017. The homeless individuals' viewpoint: Homelessness causes and resources needed to leave the sheltered environment. Social Work and Social Science Review, 19(2): $33-48$.

HEERDE, J. A., \& PALLOTTA-CHIAROLLI, M. 2020. "I've seen my friend get chopped": The influence of peer networks on exposure to violence among homeless young adults. Journal of Adolescent Research, 36(3): 247-273..

HORSELL, C. 2017. A politics of compassion: Informing a new social policy for homelessness? International Social Work, 60(4): 966-975.

HUDSON, N. 2016. The trauma of poverty as social identity. Journal of Loss and Trauma, 21(2): 111123.

IBRAHIMA, A. B., \& MATTAINI, M. A. 2019. Social work in Africa: Decolonizing methodologies and approaches. International Social Work, 62(2): 799-813.

IOVU, M. B. 2019. Usage of human rights practice by Romanian social workers. International Social Work, 0(0): 1-15.

JAMAL, A. 2019. Angels of mercy or smiling western invaders? Communities perception of NGOs in Northwest Pakistan. International Social Work, 62(1): 89-104.

JOHNSEN, S., WATTS, B., \& FITZPATRICK, S. 2020. Rebalancing the rhetoric: A normative analysis of enforcement in street homelessness policy. Urban Studies, 58(2): 355-371.

KALOUDIS, G. 2017. Non-governmental organisations: Mostly a force for good. International Journal on World Peace, 34(1): 81-112.

KGATLA, S. T. 2013. Forced removals and migration: A theology of resistance and liberation in South Africa. Missionalia, 41(2): 120-132.

KOK, P., CROSS, C., \& ROUX, N. 2010. Towards a demographic profile of the street homeless in South Africa. Development Southern Africa, 27(1): 21-37.

KUMAR, A. 2015. Rural households' access to basic amenities in India: Deprivation and socio-economic exclusions. Social Change, 45(4): 561-586.

LEIJTEN, I., \& DE BEL, K. 2020. Facing financialization in the housing sector: A human right to adequate housing for all. Netherlands Quarterly of Human Rights, 38(2): 94-114.

LOUGH, B. 2008. Engaging the poor to challenge corrupt governance. International Social Work, 51(4): 532-543.

MANGAYI, C. 2014. Poverty marginalisation and the quest for collective wellbeing in the context of homelessness in the City of Tshwane. Missionalia, 43(3): 212-235.

MANOMANO, T. 2018. Housing programmes and social work amenities in the Amathole District of the Eastern Cape. South African Journal of Social Work and Social Development, 30(2): 1-23.

Social Work/Maatskaplike Werk 2021:57(4) 
MANTHORPE, J., CORNES, M., O'HALLORANS, S., \& JOLY, L. 2015. Multiple exclusion: The preventive function of social work. British Journal of Social Work, 45: 587-599.

MAY, J. R., \& DALY, E. 2020. Dignity Rights for a pandemic. Law, Culture and the Humanities, $0(0): 1-20$.

McCLUSKEY, G \& LEPHALALA, M. 2010. 'A person is a person because of others': Challenges to meanings of discipline in South African and UK schools. Power and Education, 2(1): 18-30.

MEANWELL, E. 2012. Experiencing homelessness: A review of recent literature. Sociology Compass, 6(1): $72-85$.

MISHRA, U. S. \& SHUKLA, V. 2015. Provisions of basic household amenities in India: A progress report. Social Change, 45(3): 421-439.

MORROW, S. 2010. The homeless in historical context. Development Southern Africa, 27(1): 51-62.

MOYA, E. M., CHAVEZ-BARAY, S. M., MARTINEZ, O., MATTERA, B., \& ADCOX, C. 2018. Bridging the gap between micro and macro practice to address homelessness in the U.S - Mexico Border Region: Implications for practitioners and community stakeholders. Reflections Volume, 24(1): 102118.

MUGUMBATE, J. \& CHERENI, A. 2019. Using African Ubuntu theory in social work with children in Zimbabwe. African Journal of Social Work, 9(1): 27-34.

MUGUMBATE, J. \& NYANGURU, A. 2013. Exploring African philosophy: The value of Ubuntu in social work. African Journal of Social Work, 3: 82-100.

MUNISA, R. K. 2010. The function of NGOs in addressing gender inequality and HIV/AIDS in Uganda. Canadian Journal of African Studies, 44(3): 605-623.

NATIONAL PLANNING COMMISSION. 2012. Our future - make it work: National Development Plan 2030, Executive Summary. Pretoria: Department of Presidency, Republic of South Africa.

NGUNJIRI, F. W. 2016. “I am because we are”: exploring women's leadership under ubuntu worldview. Advances in Developing Human Resources, 18(2): 223-242.

NTAKIRUTIMANA, E. 2015. Facing homeless people in the inner City of Tshwane. A missiological conversation with the Wesleyan tradition. University of South Africa, Pretoria. (Doctoral thesis)

ORJUELA, C., HERATH, D., \& LINDBERG, J. 2016. Corrupt peace? Corruption and ethnic divides in post-war Sri Lanka. Journal of South Asian Development, 1(2): 149-174.

PADGETT, D. K. \& PRIYAM, P. 2019. Gender, everyday resistance and bodily integrity: Women's lives on Delhi streets. Journal of Female and Social Work, 34(2): 170-185.

PARSELL, C., TOMASZEWSKI, W., \& PHILLIP, R. 2014. Existing unsheltered homelessness and sustaining housing: A human agency perspective. Social Service Review, 88(2): 295-321.

PATEL, L. 2015. Social welfare and social development. Oxford: Oxford University Press.

PHILLIPS, D. \& KUYINI, A. B. 2018. Consumer participation at specialist homelessness services: Do the homeless have a say in the services they receive. International Social Work, 61(6): 1095-1115.

PIERSON, J. 2010. Tackling social exclusion. $2^{\text {nd }}$ ed. United State of America: Routledge.

POSPĚCH, P. 2020. Homeless people in public space and the politics of (in) visibility. Space and Culture, 0(0): 1-14.

PRINSLOO, R. \& VAN DER BERGH, C. 2017. Strength-based services offered to the homeless by nongovernmental and faith-based organisations in Tshwane region three, South Africa. Social Work and Social Sciences Review, 19(2): 33-46. 
QUAN-BAFFOUR, K. P \& ROOM, N. R. A. 2015. Ubuntu - inspired training of adult literacy teachers as a route to generating "community" enterprises. Journal of Literacy Research, 46(4): 455-474.

RAYBURN, R. L. \& GUITTAR, N. A. 2013. "This is where you are supposed to be": How homeless people cope with stigma. Sociological Spectrum, 33: 159-174.

RENKIN, W. 2015. Finding a prophetic response to end homelessness in the City of Tshwane: A transdisciplinary approach. University of Pretoria, Pretoria. (Masters' thesis)

REPUBLIC OF SOUTH AFRICA (RSA). 1996. Constitution of the Republic of South Africa. Government Gazette, Vol. 378, No. 17678 (8 May 1996). Pretoria: Government Printer.

RUSENKO, R. M. 2018. Imperatives of care and control in the regulation of homelessness in Kuala Lumpur, Malaysia: 1880s to present. Urban Studies, 55(10): 2123-2141.

ŠADIĆ, S., MCPHERSON, J., VILLARREAL-OTÁLORA, T., \& BAŠIĆ, S. 2020. Rights-based social work in Bosnia and Herzegovina: Validating tools for education and practice. International Social Work, 0(0): 1-14.

SAMPLE, K., \& FERGUSON, K. M. 2020. It shouldn't be this hard: Systemic, situational, and intrapersonal barriers to exiting homelessness among homeless young adults. Qualitative Social Work, 19(4): 580-598.

SANCHEZ, D. 2010. Civil society responses to homelessness. Development Southern Africa, 27(1): 101-110.

SCHENCK, R., ROMAN, N., ERASMUS, C., BLAAUW, D., \& RYAN, J. 2017. Homeless in observatory, Cape Town through the lens of Max-Neef's Fundamental human's needs taxonomy. Social Work/MaatskaplikeWerk, 53(2): 265-287.

SCHREIBER, R \& TOMM-BONDE, L. 2015. Ubuntu and constructivist grounded theory: An African methodology package. Journal of Research in Nursing, 20(8): 655-664.

SEWPAUL, V. 2016. Politics with soul: Social work and the legacy of Nelson Mandela. International Social Work, 59(6): 697-708.

SHAVA, E. 2019. Accountability of non-governmental organisations in poverty alleviation programmes. African Insights, 49(1): 122-136.

SHIMEI, N., KRUMER-NEVO, M., SAAR-HEIMAN, Y., RUSSO-CARMEL, S., MIRMOVITCH, I., ZAITOUN-ARICHA, L., \& SOCIAL WORK FOR CHANGE GROUP MEMBERS. 2016. Critical social work: A performance ethnography. Qualitative Inquiry, 22(8): 615-623.

SIMOES, A. \& SAPETA, P. 2019. The concept of dignity in nursing care: A theoretical analysis of the ethics of care. Revista Bioética, 27(2): 244-252.

SINGH, N., KOIRI, P., \& SHUKLA, S. K. 2018. Signposting invisibles: A study of the homeless population in India. Chinese Sociological Dialogue, 3(3): 179-196.

THOMPSON, S. J., RYAN, T., MONTGOMERY, K. L., LIPPMAN, A. D. P., BENDER, K., \& FERGUSON, K. 2016. Perceptions of resiliency and coping: Homeless young adults speak out. Youth and Society, 48(1): 58-76.

TOOLIS, E. E. \& HAMMACK, P. L. 2015. The lived experience of homeless youth: A narrative approach. Qualitative Psychology, 2(1): 50-68.

UNITED NATIONS. 2015. Universal declaration of human rights. New York: UN Department of Public Information.

VAN BREDA, A.D. 2012. Stigma as 'othering' among Christian theology students in South Africa. SAHARA-J: Journal of Social Aspects of HIV/AIDS, 9: 181-191.

Social Work/Maatskaplike Werk 2021:57(4) 
VAN BREDA, A. D. 2019. Developing the notion of Ubuntu as African theory for social work practice. Social Work/ Maatskaplike Werk, 55(4): 438-450.

WATSON, J. \& CUERVO, H., 2017. Youth homelessness: A social justice approach. Journal of Sociology, 53(2): 461-475.

WU, H., \& KARABANOW, J. 2020. COVID-19 and beyond: social work interventions for supporting homeless populations. International Social Work, 63(6): 790-794.

YOUNG, A., \& PETTY, J. 2019. On visible homelessness and the micro-aesthetics of public space. Australian \& New Zealand Journal of Criminology, 52(4): 444-461. 